\title{
Pathogen-specific immune fingerprints during acute infection: the diagnostic potential of human $\gamma \delta$ T-cells
}

\author{
Matthias Eberl ${ }^{1}$ *, Ida M. Friberg ${ }^{1}$, Anna Rita Liuzzi ${ }^{1}$, Matt P. Morgan ${ }^{1,2}$ and Nicholas Topley ${ }^{3}$ \\ ${ }^{1}$ Cardiff Institute of Infection and Immunity, School of Medicine, Cardiff University, Cardiff, UK \\ ${ }^{2}$ Cardiff and Vale University Health Board, Cardiff, UK \\ ${ }^{3}$ Institute of Translation, Innovation, Methodology and Engagement, School of Medicine, Cardiff University, Cardiff, UK \\ *Correspondence: eberlm@cf.ac.uk \\ Edited by: \\ Julie Dechanet-Merville, Centre National de la Recherche Scientifique, France \\ Reviewed by: \\ Bernhard Moser, Cardiff University, UK \\ Dieter Kabelitz, Christian-Albrechts University Kiel, Germany
}

Keywords: bacterial infection, point-of-care diagnosis, biomarkers, innate immunity, local inflammation

\section{APOCALYPSE NOW: THE END OF MODERN MEDICINE AS WE KNOW IT}

Gentlemen, it is the microbes who will have the last word. [Messieurs, c'est les microbes qui auront le dernier mot]. - Louis Pasteur, 1822-1895

The last 200 years have seen a dramatic reduction in the prevalence and severity of microbial infections, due to the implementation of groundbreaking measures ranging from improved sanitation and hygiene and the introduction of aseptic techniques to the development of successful vaccines and the discovery of effective antibiotics. Devastating infections that were common until the late nineteenth century such as cholera, diphtheria, plague, syphilis, tuberculosis, and typhoid came into the reach of effective control, at least in developed countries, and with a minimized risk of wound infections surgical procedures began to revolutionize modern medicine. Antibiotics, in particular, radically transformed the treatment and prevention of microbial infections and have saved millions of lives since their introduction (1). However, antibiotic usage is invariably linked to the selective pressure it exerts on the target organism to develop escape strategies (2).

We are at present witnessing how the pendulum begins to swing backwards, with anti-microbial resistances developing on an unprecedented global scale. New classes of Gram-positive and Gramnegative "superbugs" are emerging and spreading at an alarming rate, some of which are virtually insusceptible to all available drugs (3-5). The once apocalyptic vision of a "post-antibiotic era" where common infections and minor injuries may result untreatable and eventually fatal is rapidly becoming a real possibility ( 1 , 2, 6, 7), heralding what Margaret Chan, Director-General of the WHO, in 2012 called "the end of modern medicine as we know it." The appearance of multidrugresistant bacteria has been identified by the WHO, the Centers for Disease Control and Prevention (CDC) in the USA and their European counterpart, the ECDC, as one of the major global health challenges humankind is facing in the twentyfirst century (8-10). According to Sally Davies, the UK Chief Medical Officer, "there are few public health issues of greater importance than anti-microbial resistance in terms of impact on society" (11).

There is now an urgent call for antimicrobial stewardship programs that aim to prescribe antibiotics more prudently, and to tailor their use to defined patient groups who will benefit most. The fact that the prevalence of resistance appears to correlate directly with antibiotic consumption across different countries (12) argues in favor of the immediate effectiveness of such tightly controlled programs. As highlighted in a recent Outlook issue in Nature, "the potential to save lives with faster and more targeted diagnoses, decrease unnecessary and often incorrect prescriptions, and even help identify early on where bacterial resistance could occur, will have a drastic effect on the way patients are treated" (13).

\section{MISSION IMPOSSIBLE: THE FUNDAMENTAL FLAWS OF CONVENTIONAL DIAGNOSIS}

When it concerns the search for pathogenic organisms suspected in the diseased body, in the first instance bacteria, then during conventional microscopic examination carried out without special preparations and artifices one encounters the most substantial, at times virtually insurmountable, obstacles. [Wenn es sich nun darum handelt, die im erkrankten Körper vermutheten pathogenen Organismen, zunächst Bacterien, aufzusuchen, so begegnet man bei der gewöhnlichen ohne besondere Vorbereitungen und Kunstgriffe ausgeführten mikroskopischen Untersuchung den erheblichsten, stellenweise geradezu unübersteiglichen Hindernissen]. Robert Koch, 1843-1910 (14)

More than a century after Robert Koch's landmark discovery of the causative agents of anthrax, cholera, and tuberculosis, the diagnosis of suspected infections still depends largely on the definitive identification of the likely pathogen in biological samples. However, standard microbiological culture is inefficient and slow (typically $>1-2$ days, for a confirmed diagnosis of tuberculosis $>4$ weeks), and in many cases no organism can be grown despite 
clinical signs of infection, indicating that conventional diagnostic methods are not specific and/or rapid enough to target therapy (15-17). Early management of patients with acute symptoms who require immediate medical intervention, including virtually all hospital-based infections, thus remains largely empirical. As direct consequence, the fundamental uncertainty about the real cause underlying the clinical signs observed leads to inappropriate and unnecessary treatments exposing patients to drug-related side effects; raising the risk of opportunistic, chronic, or recurrent infections; and contributing to the emergence and spread of multidrug resistance (1-7). This dilemma eventually results in potentially avoidable patient morbidity/mortality, and imposes a considerable burden on health care systems and societies (8-11). There remains an unmet clinical need for rapid and accurate diagnostic tests for patients with acute infections. According to Kessel and Sharland (18), "new technology focusing on rapid diagnosis of specific bacteria and resistance genes, along with combination biomarkers indicating bacterial or viral infections, especially if adapted to near patient testing, could have a major impact on targeting appropriate antibiotic treatment."

In order to circumvent the almost insurmountable obstacles of a rapid and accurate identification of the causative pathogen by traditional microbiological techniques, efforts are being made to utilize state-of-the-art molecular methods. Approaches based on the detection of microbial nucleic acids, cell wall constituents, or other unique features of distinct pathogens by PCR, chromatography, or mass spectrometry certainly complement culture-based tests and speed up microbial identification, yet they require considerable resources and may not be applicable to primary care or home settings (19-23). Moreover, they do not provide information about the pathogenicity of the identified species and its interaction with the host. Of note, neither microbiological nor molecular methods discriminate between pathogens causing disease, asymptomatic carriage, and sample contaminants, and thus even positive test results require extensive interpretation by the treating physician (24-26).
There is a plethora of disease-related markers that are commonly assessed by clinicians to aid a correct diagnosis, ranging from basic blood and urine parameters to indicators of tissue damage, tumor progression and autoimmunity, among others. However, there is a conspicuous paucity of biomarkers for accurate diagnosis of microbial disease. Current biomarkers of inflammation such as C-reactive protein (CRP) or procalcitonin (PCT) are often not sensitive or specific enough and are only poor surrogates for acute infections $(22,27,28)$. The vast majority of research on novel diagnostics has so far focused on identifying individual factors and assessing their performance in isolation. Yet, it may come as no surprise that none of these proposed parameters have reached sufficient discriminatory power on their own, given the complex and multifactorial processes underlying local and systemic inflammatory responses to a broad range of pathogens $(29,30)$. As a result, neither the direct identification of the causative pathogen nor the measurement of currently used biomarkers of inflammation is sufficiently accurate or rapid for a reliable point-of-care diagnosis of acute microbial infection.

\section{QUANTUM OF SOLACE: EXPLOITATION OF PATHOGEN-SPECIFIC HOST RESPONSES FOR NOVEL DIAGNOSTICS}

The immune system appears to have originated as a set of effector cells having multiple distinct receptors that discriminate self from infectious non-self by recognition of patterns found exclusively on microorganisms. - Charles A. Janeway, Jr., 1943-2003 (31)

Key to developing better and stratified approaches to treating infection is a detailed understanding of the intricate host-pathogen relationships in disease, in order to exploit the unique sophistication of the human immune system for diagnostic and therapeutic purposes (32, 33). In a radical departure from current practice, our research is based upon the premise that each type of infection evokes a distinct pathogen-specific host response what we refer to as "immune fingerprint." A patient's early anti-microbial response itself is likely to provide far more detailed insight into the true cause and severity of acute infections than conventional methods, independently of the subsequent clinical course of the disease (34). The human immune system is a highly complex network of interdependent cellular and humoral players that has evolved over millions of years in order to survey the body for potentially hazardous structures and initiate an appropriate defense. The communication with invading micro-organisms thus occurs at multiple levels, giving rise to a plethora of biomarkers of potential relevance for diagnostic purposes. Different pathogens interact uniquely with different components of the innate immune system due to the efficient self/non-self discrimination based on conserved microbial signals such as non-methylated bacterial DNA, bacterial flagella, and cell wall constituents. These structures are typically recognized by members of the Toll-like receptor family and/or other pattern recognition receptors expressed by sentinel cells (35-37). However, there is also emerging evidence that certain types of innate or "unconventional" T-cells such as $\gamma \delta \mathrm{T}$ cells and mucosal-associated invariant $\mathrm{T}$ (MAIT) cells are able to detect common microbial metabolites through their T-cell receptors, by sensing intermediates of the non-mevalonate and riboflavin biosynthesis pathways that are unique to certain types of microorganisms $(38,39)$.

$\mathrm{V} \gamma 9 / \mathrm{V} \delta 2$ T-cells represent a unique subpopulation of human T-cells $(40,41)$ that appears to have a particularly crucial role in contributing to immune fingerprints of diagnostic relevance (34). This is due to their exquisite responsiveness to the microbial isoprenoid precursor $(E)$ 4-hydroxy-3-methyl-but-2-enyl pyrophosphate (HMB-PP) that is produced by the majority of Gram-negative pathogens and a large proportion of Gram-positive species such as Clostridium difficile, Listeria monocytogenes, and Mycobacterium tuberculosis, while it is not found in other bacteria including staphylococci and streptococci as well as fungi (42-44). The rapid and sensitive response of $\mathrm{V} \gamma 9 / \mathrm{V} \delta 2 \mathrm{~T}$-cells to a broad range of pathogens evokes Janeway's criteria for a "pathogen-associated molecular pattern" in that HMB-PP is an invariant metabolite in many different species that is essential in the microbial physiology but absent from the human 
host $(43,45)$. Bacterial extracts prepared from $\mathrm{HMB}-\mathrm{PP}$ producing species typically activate $\mathrm{V} \gamma 9 / \mathrm{V} \delta 2$ T-cells much stronger than extracts prepared from HMB-PP deficient micro-organisms (42, 44, 46), and peripheral and/or local $\mathrm{V} \gamma 9 / \mathrm{V} \delta 2 \mathrm{~T}$ cell levels are often elevated in patients infected with defined HMB-PP producing pathogens $(43,47)$. Elegant proof of concept for this responsiveness comes from the demonstration that HMB-PP producing wildtype L. monocytogenes activate $\mathrm{V} \gamma 9 / \mathrm{V} \delta 2 \mathrm{~T}$-cells far better, both in vitro (48) and in primate models in vivo (49), than genetically engineered L. monocytogenes that are identical to the parental strain except for an inability to produce HMB-PP. Similarly, overexpression of HMB-PP synthase through genetic manipulation increases the stimulatory potential of bacteria such as E. coli, L. monocytogenes, M. tuberculosis, and Salmonella enterica on V $\gamma 9 / \mathrm{V} \delta 2$ T-cells in vitro (42, $46,48,50,51)$ and in vivo (52). Our own data demonstrate that even in heterogeneous patient cohorts infected with a whole spectrum of diverse bacteria, differences in $\mathrm{V} \gamma 9 / \mathrm{V} \delta 2 \mathrm{~T}$-cell frequencies between patients with microbiologically confirmed infections caused by HMB-PP producing and HMB-PP deficient species remain apparent. This is true both for peritoneal dialysis patients with acute peritonitis as an exemplar of localized immune responses restricted to the peritoneal cavity $(34,46,53)$, as well as on a systemic level in the peripheral blood of critically ill patients with severe sepsis (54). Most importantly, studies in patients with acute peritonitis suggest that a diagnostic test measuring local $\mathrm{V} \gamma 9 / \mathrm{V} \delta 2 \mathrm{~T}$ cells on the first day of presentation with acute symptoms may not only indicate the presence of Gram-negative (predominantly HMB-PP producing) bacteria but also identify patients at an increased risk of inflammation-related downstream complications (34).

The exquisite responsiveness of V $\gamma 9 / \mathrm{V} \delta 2$ T-cells and other unconventional T-cells to microbial metabolites shared by certain pathogens but not by others identifies these cell types as key constituent of diagnostically relevant immune fingerprints at the point of care. This is especially the case when $\mathrm{V} \gamma 9 / \mathrm{V} \delta 2$ $\mathrm{T}$-cell levels are assessed locally and when they are combined with other powerful discriminators such as peritoneal proportions of neutrophils, monocytes, and $\mathrm{CD} 4^{+}$ T-cells in the inflammatory infiltrate as well as intraperitoneal concentrations of certain soluble immune mediators (34) (Figure 1). Such a combination with further parameters provides additional information as to the precise nature of the causative pathogen, for instance to distinguish between immune responses induced by Gram-negative (LPS producing) and Gram-positive (LPS deficient) bacteria, and is also likely to help increase sensitivity owing to the age and genderdependent variability of $\mathrm{V} \gamma 9 / \mathrm{V} \delta 2$ T-cell levels (55). Pathogen-specific immune fingerprints that discriminate between certain subgroups of patients (e.g., with Gram-negative vs. Gram-positive bacterial infections) can be determined within hours of presentation with acute symptoms, long before traditional culture results become available, and by guiding early patient

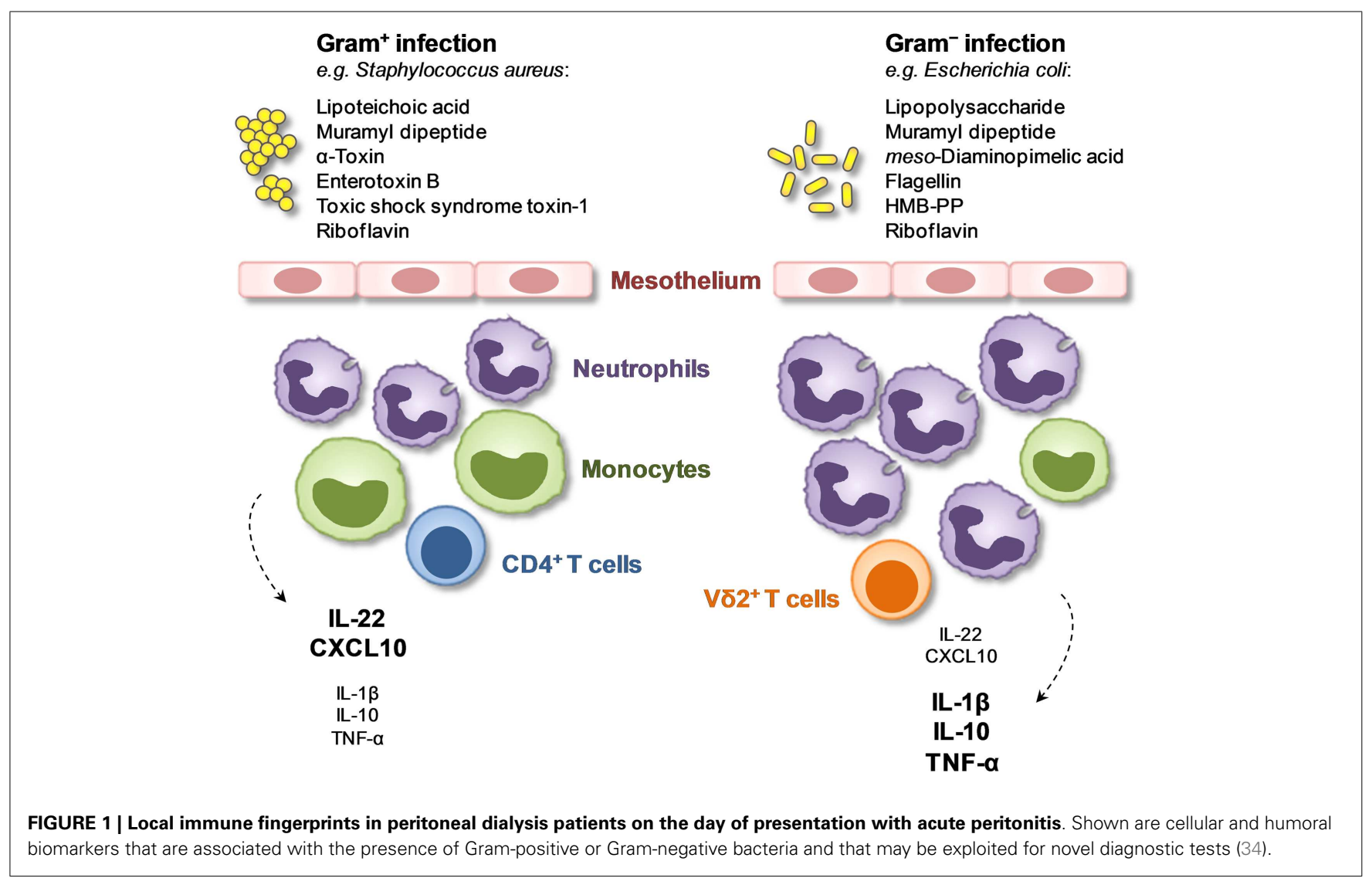


management and optimizing targeted treatment will contribute to improving outcomes and advancing antibiotic stewardship. It remains to be investigated how much these findings on diagnostic immune fingerprints in peritoneal dialysis patients can be extended to other local or systemic scenarios to diagnose infections at the point of care, and whether they can also be applied to monitoring the course of the disease and the response to treatment.

Applied research on $\gamma \delta$ T-cells has so far focused predominantly on their use for novel immunotherapies against different types of cancers (56-58). Thirty years after the unexpected cloning of the TCR $\gamma$ chain $(59,60)$ and 20 years after the first description of microbial "phosphoantigens" as specific activators of human $\mathrm{V} \gamma 9 / \mathrm{V} \delta 2 \mathrm{~T}$ cells $(61,62)$, the diagnostic potential of $\gamma \delta$ T-cells is only beginning to unfold $(34,47$, $63,64)$.

\section{ACKNOWLEDGMENTS}

The work described has received support from the UK Clinical Research Network Study Portfolio, NISCHR/Wellcome Trust Institutional Strategic Support Fund, NIHR Invention for Innovation Programme, Baxter Healthcare Renal Discoveries Extramural Grant Programme, SARTRE/SEWAHSP Health Technology Challenge Scheme, MRC Confidence in Concept scheme, and EU-FP7 Initial Training Network "European Training \& Research in Peritoneal Dialysis" (EuTRiPD).

\section{REFERENCES}

1. Fauci AS, Morens DM. The perpetual challenge of infectious diseases. N Engl J Med (2012) 366(5):454-61. doi:10.1056/nejmra1 108296

2. Hede K. Antibiotic resistance: an infectious arms race. Nature (2014) 509(7498):S2-3. doi:10.1038/ 509S2a

3. Kumarasamy KK, Toleman MA, Walsh TR, Bagaria J, Butt F, Balakrishnan R, et al. Emergence of a new antibiotic resistance mechanism in India, Pakistan, and the UK: a molecular, biological, and epidemiological study. Lancet Infect Dis (2010) 10(9):597-602. doi:10.1016/S14733099(10)70143-2

4. Davey MS, Tyrrell JM, Howe RA, Walsh TR, Moser B, Toleman MA, et al. A promising target for treatment of multidrug-resistant bacterial infections. Antimicrob Agents Chemother (2011) 55(7):3635-6. doi:10.1128/aac.00382-11

5. Edelstein MV, Skleenova EN, Shevchenko OV, D’Souza JW, Tapalski DV, Azizov IS, et al. Spread of extensively resistant VIM-2-positive
ST235 Pseudomonas aeruginosa in Belarus, Kazakhstan, and Russia: a longitudinal epidemiological and clinical study. Lancet Infect Dis (2013) 13(10):867-76. doi:10.1016/S14733099(13)70168-3

6. Livermore DM. Has the era of untreatable infections arrived? J Antimicrob Chemother (2009) 64(Suppl 1):i29-36. doi:10.1093/jac/dkp255

7. Arias CA, Murray BE. Antibiotic-resistant bugs in the 21st century - a clinical super-challenge. N Engl J Med (2009) 360(5):439-43. doi:10.1056/ nejmp0804651

8. Antimicrobial Resistance: Global Report on Surveillance 2014. World Health Organisation. (2014). Available from: http://www.who.int/ drugresistance

9. Annual Epidemiological Report 2012 - Reporting on 2010 Surveillance Data and 2011 Epidemic Intelligence Data. European Centre for Disease Prevention and Control. Stockholm: ECDC (2013).

10. Antibiotic Resistance Threats in the United States 2013. Centers for Disease Control and Prevention. (2013). Available from: http://www.cdc.gov/ drugresistance/threat-report-2013

11. UK Five Year Antimicrobial Resistance Strategy2013 to 2018. UK Department of Health. (2013). Available from: https:// www.gov.uk/government/publications/uk-5-yearantimicrobial-resistance-strategy-2013-to-2018

12. van de Sande-Bruinsma N, Grundmann H, Verloo D, Tiemersma E, Monen J, Goossens H, et al. Antimicrobial drug use and resistance in Europe. Emerg Infect Dis (2008) 14(11):1722-30. doi:10. 3201/eid1411.070467

13. Kanthor R. Diagnostics: detection drives defence. Nature (2014) 509(7498):S14-5. doi:10.1038/ 509S14a

14. Koch R. Zur Untersuchung von pathogenen Organismen. Mittheilungen aus dem Kaiserlichen Gesundheitsamte (1881) 1:1-48.

15. Shafazand S, Weinacker AB. Blood cultures in the critical care unit: improving utilization and yield. Chest (2002) 122(5):1727-36. doi:10.1378/chest. 122.5.1727

16. Richards D, Toop L, Chambers S, Fletcher L. Response to antibiotics of women with symptoms of urinary tract infection but negative dipstick urine test results: double blind randomised controlled trial. BMJ (2005) 331(7509):143. doi:10. 1136/bmj.38496.452581.8F

17. Fahim M, Hawley CM, McDonald SP, Brown FG, Rosman JB, Wiggins KJ, et al. Culture-negative peritonitis in peritoneal dialysis patients in Australia: predictors, treatment, and outcomes in 435 cases. Am J Kidney Dis (2010) 55(4):690-7. doi:10. 1053/j.ajkd.2009.11.015

18. Kessel AS, Sharland M. The new UK antimicrobial resistance strategy and action plan. BMJ (2013) 346:f1601. doi:10.1136/bmj.f1601

19. Leggieri N, Rida A, François P, Schrenzel J. Molecular diagnosis of bloodstream infections: planning to (physically) reach the bedside. Curr Opin Infect Dis (2010) 23(4):311-9. doi:10.1097/qco. 0b013e32833bfc44

20. Gubala V, Harris LF, Ricco AJ, Tan MX, Williams DE. Point of care diagnostics: status and future. Anal Chem (2012) 84(2):487-515. doi:10.1021/ ac2030199
21. Bissonnette L, Bergeron MG. Infectious disease management through point-of-care personalized medicine molecular diagnostic technologies. J Pers Med (2012) 2(2):50-70. doi:10.3390/jpm2020050

22. Caliendo AM, Gilbert DN, Ginocchio CC, Hanson KE, May L, Quinn TC, et al. Better tests, better care: improved diagnostics for infectious diseases. Clin Infect Dis (2013) 57(Suppl 3):S139-70. doi: $10.1093 / \mathrm{cid} / \mathrm{cit} 578$

23. Fournier PE, Drancourt M, Colson P, Rolain JM, La Scola B, Raoult D. Modern clinical microbiology: new challenges and solutions. Nat Rev Microbiol (2013) 11(8):574-85. doi:10.1038/nrmicro3068

24. Casadevall A, Pirofski LA. Host-pathogen interactions: basic concepts of microbial commensalism, colonization, infection, and disease. Infect Immun (2000) 68(12):6511-8. doi:10.1128/IAI.68. 12.6511-6518.2000

25. Trautner BW. Asymptomatic bacteriuria: when the treatment is worse than the disease. Nat Rev Urol (2011) 9(2):85-93. doi:10.1038/nrurol.2011.192

26. Yu VL. Guidelines for hospital-acquired pneumonia and health-care-associated pneumonia: a vulnerability, a pitfall, and a fatal flaw. Lancet Infect Dis (2011) 11(3):248-52. doi:10.1016/S1473-3099(11) 70005-6

27. Tang BM, Eslick GD, Craig JC, McLean AS. Accuracy of procalcitonin for sepsis diagnosis in critically ill patients: systematic review and metaanalysis. Lancet Infect Dis (2007) 7(3):210-7. doi: 10.1016/S1473-3099(07)70052-X

28. Lam MF, Leung JC, Lam CW, Tse KC, Lo WK, Lui SL, et al. Procalcitonin fails to differentiate inflammatory status or predict long-term outcomes in peritoneal dialysis-associated peritonitis. Perit Dial Int (2008) 28(4):377-84.

29. Pierrakos C, Vincent JL. Sepsis biomarkers: a review. Crit Care (2010) 14(1):R15. doi:10.1186/ cc8872

30. Kibe S, Adams K, Barlow G. Diagnostic and prognostic biomarkers of sepsis in critical care. J Antimicrob Chemother (2011) 66(Suppl 2):ii33-40. doi:10.1093/jac/dkq523

31. Janeway CA Jr. Approaching the asymptote? Evolution and revolution in immunology. Cold Spring Harb Symp Quant Biol (1989) 54(1):1-13. doi:10. 1101/SQB.1989.054.01.003

32. Ramilo O, Allman W, Chung W, Mejias A, Ardura $\mathrm{M}$, Glaser C. Gene expression patterns in blood leukocytes discriminate patients with acute infections. Blood (2007) 109(5):2066-77. doi:10.1182/ blood-2006-02-002477

33. Mejias A, Suarez NM, Ramilo O. Detecting specific infections in children through host responses: a paradigm shift. Curr Opin Infect Dis (2014) 27(3):228-35. doi:10.1097/QCO. 0000000000000065

34. Lin CY, Roberts GW, Kift-Morgan A, Donovan KL, Topley N, Eberl M. Pathogen-specific local immune fingerprints diagnose bacterial infection in peritoneal dialysis patients. J Am Soc Nephrol (2013) 24(12):2002-9. doi:10.1681/asn. 2013040332

35. Blander JM, Sander LE. Beyond pattern recognition: five immune checkpoints for scaling the microbial threat. Nat Rev Immunol (2012) 12(3):215-25. doi:10.1038/nri3167

36. Stuart LM, Paquette N, Boyer L. Effectortriggered versus pattern-triggered immunity: how 
animals sense pathogens. Nat Rev Immunol (2013) 13(3):199-206. doi:10.1038/nri3398

37. Broz P, Monack DM. Newly described pattern recognition receptors team up against intracellular pathogens. Nat Rev Immunol (2013) 13(8):551-65. doi:10.1038/nri3479

38. Sandstrom A, Peigné CM, Léger A, Crooks JE, Konczak F, Gesnel MC, et al. The intracellular B30.2 domain of butyrophilin 3A1 binds phosphoantigens to mediate activation of human $\mathrm{V} \gamma 9 \mathrm{~V} \delta 2 \mathrm{~T}$ cells. Immunity (2014) 40(4):490-500. doi:10.1016/j.immuni.2014.03.003

39. Corbett AJ, Eckle SB, Birkinshaw RW, Liu L, Patel $\mathrm{O}$, Mahony J, et al. T-cell activation by transitory neo-antigens derived from distinct microbial pathways. Nature (2014) 509(7500):361-5. doi:10.1038/nature 13160

40. Bonneville M, O'Brien RL, Born WK. $\gamma \delta \mathrm{T}$ cell effector functions: a blend of innate programming and acquired plasticity. Nat Rev Immunol (2010) 10(7):467-78. doi:10.1038/nri2781

41. Vantourout P, Hayday A. Six-of-the-best: unique contributions of $\gamma \delta$ T cells to immunology. Nat Rev Immunol (2013) 13(2):88-100. doi:10.1038/ nri3384

42. Altincicek B, Moll J, Campos N, Foerster G, Beck E, Hoeffler JF, et al. Human $\gamma \delta$ T cells are activated by intermediates of the 2-C-methyl-D-erythritol 4-phosphate pathway of isoprenoid biosynthesis. J Immunol (2001) 166(6):3655-8. doi:10.4049/ jimmunol.166.6.3655

43. Morita CT, Jin C, Sarikonda G, Wang H. Nonpeptide antigens, presentation mechanisms, and immunological memory of human $\mathrm{V} \gamma 2 \mathrm{~V} \delta 2 \mathrm{~T}$ cells: discriminating friend from foe through the recognition of prenyl pyrophosphate antigens. Immunol Rev (2007) 215(1):59-76. doi:10.1111/j. 1600-065x.2006.00479.x

44. Eberl M, Moser B. Monocytes and $\gamma \delta \mathrm{T}$ cells: close encounters in microbial infection. Trends Immunol (2009) 30(12):562-8. doi:10.1016/j.it. 2009.09.001

45. Riganti C, Massaia M, Davey MS, Eberl M. Human $\gamma \delta$ T-cell responses in infection and immunotherapy: common mechanisms, common mediators? Eur J Immunol (2012) 42(7):1668-76. doi:10.1002/ eji.201242492

46. Davey MS, Lin CY, Roberts GW, Heuston S, Brown AC, Chess JA, et al. Human neutrophil clearance of bacterial pathogens triggers anti-microbial $\gamma \delta$ $\mathrm{T}$ cell responses in early infection. PLoS Pathog (2011) 7(5):e1002040. doi:10.1371/journal.ppat. 1002040

47. Bank I, Marcu-Malina V. Quantitative peripheral blood perturbations of $\gamma \delta \mathrm{T}$ cells in human disease and their clinical implications. Clin Rev Allergy Immunol (2014). doi:10.1007/s12016-0138391-x

48. Begley M, Gahan CG, Kollas AK, Hintz M, Hill $\mathrm{C}$, Jomaa $\mathrm{H}$, et al. The interplay between classical and alternative isoprenoid biosynthesis controls $\gamma \delta$ $\mathrm{T}$ cell bioactivity of Listeria monocytogenes. FEBS Lett (2004) 561(1-3):99-104. doi:10.1016/S00145793(04)00131-0

49. Frencher J, Shen H, Yan L, Wilson JO, Freitag NE, Rizzo AN, et al. HMBPP-deficient Listeria mutant induces altered pulmonary/systemic responses, effector functions and memory polarization of $\mathrm{V} \gamma 2 \mathrm{~V} \delta 2 \mathrm{~T}$ cells. J Leukoc Biol (2014). doi:10.1189/jlb.6HI1213-632R

50. Puan KJ, Wang H, Dairi T, Kuzuyama T, Morita CT. fldA is an essential gene required in the 2-C-methyl-D-erythritol 4-phosphate pathway for isoprenoid biosynthesis. FEBS Lett (2005) 579(17):3802-6. doi:10.1016/j.febslet.2005. 05.047

51. Brown AC, Eberl M, Crick DC, Jomaa H, Parish T. The nonmevalonate pathway of isoprenoid biosynthesis in Mycobacterium tuberculosis is essential and transcriptionally regulated by Dxs. J Bacteriol (2010) 192(9):2424-33. doi:10.1128/JB. 01402-09

52. Workalemahu G, Wang H, Puan KJ, Nada MH, Kuzuyama T, Jones BD, et al. Metabolic engineering of Salmonella vaccine bacteria to boost human $\mathrm{V} \gamma 2 \mathrm{~V} \delta 2 \mathrm{~T}$ cell immunity. I Immunol (2014) 193(2):708-21. doi:10.4049/jimmunol. 1302746

53. Eberl M, Roberts GW, Meuter S, Williams JD, Topley N, Moser B. A rapid crosstalk of human $\gamma \delta \mathrm{T}$ cells and monocytes drives the acute inflammation in bacterial infections. PLoS Pathog (2009) 5(2):e1000308. doi:10.1371/journal.ppat. 1000308

54. Davey MS, Morgan MP, Liuzzi AR, Tyler CJ, Khan MWA, Szakmany T, et al. Microbe-specific unconventional $\mathrm{T}$ cells induce human neutrophil differentiation into antigen cross-presenting cells. J Immunol (2014) 193:3704-16. doi:10.4049/ jimmunol.1401018

55. Caccamo N, Dieli F, Wesch D, Jomaa H, Eberl M. Sex-specific phenotypical and functional differences in peripheral human $\mathrm{V} \gamma 9 / \mathrm{V} \delta 2 \mathrm{~T}$ cells. J Leukoc Biol (2006) 79(4):663-6. doi:10.1189/jlb. 1105640

56. Gomes AQ, Martins DS, Silva-Santos B. Targeting $\gamma \delta \mathrm{T}$ lymphocytes for cancer immunotherapy: from novel mechanistic insight to clinical application. Cancer Res (2010) 70(24):10024-7. doi:10.1158/0008-5472.can-10-3236

57. Moser B, Eberl M. $\gamma \delta$ T-APCs: a novel tool for immunotherapy? Cell Mol Life Sci (2011) 68(14):2443-52. doi:10.1007/s00018-011-0706-6

58. Fisher JP, Heuijerjans J, Yan M, Gustafsson K, Anderson J. $\gamma \delta$ T cells for cancer immunotherapy: a systematic review of clinical trials. Oncoimmunology (2014) 3(1):e27572. doi:10.4161/onci.27572

59. Saito H, Kranz DM, Takagaki Y, Hayday AC, Eisen HN, Tonegawa S. Complete primary structure of a heterodimeric T-cell receptor deduced from cDNA sequences. Nature (1984) 309(5971):757-62. doi: 10.1016/0092-8674(85)90140-0

60. Hayday AC, Saito H, Gillies SD, Kranz DM, Tanigawa G, Eisen HN, et al. Structure, organization, and somatic rearrangement of $\mathrm{T}$ cell gamma genes. Cell (1985) 40(2):259-69. doi:10.1016/ 0092-8674(85)90140-0

61. Constant P, Davodeau F, Peyrat MA, Poquet Y, Puzo G, Bonneville M, et al. Stimulation of human $\gamma \delta \mathrm{T}$ cells by nonpeptidic mycobacterial ligands. Science (1994) 264(5156):267-70. doi:10.1126/ science. 8146660

62. Tanaka Y, Morita CT, Tanaka Y, Nieves E, Brenner $\mathrm{MB}$, Bloom BR. Natural and synthetic non-peptide antigens recognized by human $\gamma \delta \mathrm{T}$ cells. Nature (1995) 375(6527):155-8. doi:10.1038/375155a0

63. Welton JL, Morgan MP, Martí S, Stone MD, Moser B, Sewell AK, et al. Monocytes and $\gamma \delta \mathrm{T}$ cells control the acute-phase response to intravenous zoledronate: insights from a phase IV safety trial. J Bone Miner Res (2013) 28(3):464-71. doi:10.1002/jbmr. 1797

64. Welton JL, Martí S, Mahdi MH, Boobier C, Barrett-Lee PJ, Eberl M. $\gamma \delta \mathrm{T}$ cells predict outcome in zoledronate-treated breast cancer patients. Oncologist (2013) 18(8):e22-3. doi:10. 1634/theoncologist.2013-0097

Conflict of Interest Statement: The authors declare that the research was conducted in the absence of any commercial or financial relationships that could be construed as a potential conflict of interest. The Specialty Chief Editor Bernhard Moser declares that, despite being affiliated to the same department as authors Matthias Eberl, Ida M. Friberg, Anna Rita Liuzzi, Matt P. Morgan and being affiliated to the same institution as Nicholas Topley, and despite having collaborated on publications in the last 2 years with Matthias Eberl, Anna Rita Liuzzi, Matt P. Morgan and Nicholas Topley, the review process was handled objectively.

Received: 19 July 2014; accepted: 26 October 2014; published online: 13 November 2014.

Citation: Eberl M, Friberg IM, Liuzzi AR, Morgan MP and Topley N (2014) Pathogen-specific immune fingerprints during acute infection: the diagnostic potential of human $\gamma \delta$ T-cells. Front. Immunol. 5:572. doi: 10.3389/fimmu.2014.00572

This article was submitted to T Cell Biology, a section of the journal Frontiers in Immunology.

Copyright $\odot 2014$ Eberl, Friberg, Liuzzi, Morgan and Topley. This is an open-access article distributed under the terms of the Creative Commons Attribution License (CC BY). The use, distribution or reproduction in other forums is permitted, provided the original author(s) or licensor are credited and that the original publication in this journal is cited, in accordance with accepted academic practice. No use, distribution or reproduction is permitted which does not comply with these terms. 